
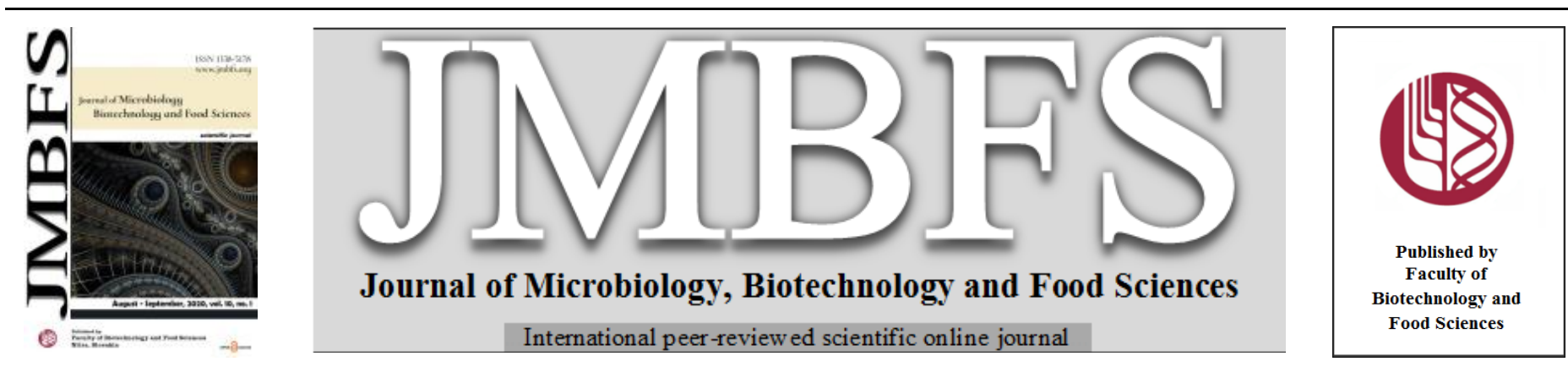

\title{
EFFECT OF GRAPE POMACE SUPPLEMENTATION ON MEAT PERFORMANCE OF BROILER CHICKEN ROSS 308
}

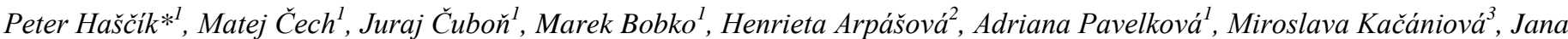 Tkáčovál ${ }^{\text {, Natália Čeryovál }}$}

\author{
$\operatorname{Address}(e s)$ : \\ ${ }^{1}$ Slovak University of Agriculture in Nitra, Faculty of Biotechnology and Food Sciences, Department of Animal Products Evaluation and Processing, Tr. A. Hlinku 2 , \\ 94976 Nitra, Slovakia \\ ${ }^{2}$ Slovak University of Agriculture in Nitra, Faculty of Agrobiology and Food Resources, Department of Poultry and Small Farm Animals, Tr. A. Hlinku 2, 94976 \\ Nitra, Slovakia \\ ${ }^{3}$ Slovak University of Agriculture in Nitra, Faculty of Horticulture and Landscape Engineering, Department of Fruit Science, Viticulture and Enology, Tr. A. Hlinku 2, \\ 94976 Nitra, Slovakia
}

*Corresponding author: peter.hascik@uniag.sk

doi: 10.15414/jmbfs.2020.10.1.140-144

\section{ARTICLE INFO}

Received 8. 4. 2020

Revised 14. 5. 2020

Accepted 19. 5. 2020

Published 1. 8. 2020

Regular article

OPEN $\partial_{\text {ACCESS }}$

\begin{abstract}
The aim was the evaluavate meat performance of broiler chickens Ross 308 after the addition of red grape pomace (variety Alibernet) into their diet. A total of one-day 200 Ross 308 broiler chickens of males and females were randomly divided into 4 groups $(\mathrm{n}=50$ ): the control group (C) without additional supplementation, experimental group E1 supplemented with $1 \%$ red grape pomace per $1 \mathrm{~kg}$ of feed mixture, experimental group E2 supplemented with $2 \%$ red grape pomace per $1 \mathrm{~kg}$ of feed mixture and experimental group E3 supplemented with $3 \%$ red grape pomace per $1 \mathrm{~kg}$ of feed mixture. The feed mixtures were produced without any antibiotics and coccidiostatics. The fattening period lasted for 42 days. The findings of the work on the meat performance and carcass characteristics of Ross 308 broiler chickens revealed that grape pomace in amount 3\% (E3 group) seems to be the most suitable feed supplement. Among the most positively affected parameters $(\mathrm{P} \leq 0.05)$ by this supplementation in comparison with control may be mentioned the live weight and breast part weight $(\hat{\delta}, \phi$ and $\hat{\delta}+q)$. Moreover, it seems likely that any supplementation with grape pomace can positively affect $(\mathrm{P} \leq 0.05)$ giblets weight $(\hat{\delta}+q)$ and necks weight $(q$ and $\hat{\delta}+q)$.
\end{abstract}

Keywords: nutrition, chicken meat, grape pomace, meat performance

\section{INTRODUCTION}

Among livestock, poultry is one of the most important because it provides us with high-quality proteins and micronutrients through meat and eggs, which the human body absorbs more easily than plant products (Raza et al., 2019). After two years of sluggish growth, world poultry meat output is forecast to expand by $2.8 \%$ to 128 million tonnes, showing signs of regained vigour. This year's positive outlook is due to the successful containment of the Highly Pathogenic Avian Influenza (HPAI) spreading and the strong potential for poultry meat to be used as a substitute for pork meat. The expected expansion in global poultry meat production would mostly occur in China, the EU, Brazil, the United States of America, India, Pakistan and Mexico, with smaller expansions in Turkey, Colombia and Thailand (FAO, 2019). Poultry meat and poultry products are of a great importance in human nutrition worldwide, as they contribute global food security thanks to their availability. They provide an excellent source of proteins, fats, essential amino acids, minerals, vitamins and other nutrients (Shaltout, 2019).

The indistinct taste and high tenderness of chicken breasts enable the production of a variety of meat products, which are aimed at different groups of consumers. In addition, chicken breast meat is suitable for quick and undemanding preparation, which is popular especially nowadays, when people tend to spend less and less time preparing meals at home (Petracci et al., 2013). The great advantage of chicken meat is also that, unlike other types of meat, there are no religious and social restrictions for its consumption. In addition, it is also relatively cheap (Haščík et al., 2018). It is generally more represented in the city inhabitants' diet than in the countryside, where poor in full-value proteins cereals predominate. Those full-value proteins, resp. the essential amino acids lysine, threonine and sulphur methionine and cysteine are present in chicken meat. Compared to the red meat of large farm animals, chicken meat is generally considered healthier. The breast muscle of chickens contains less than $3 \mathrm{~g}$ fat.100 $\mathrm{g}^{-1}$ meat, while red meat contains approximately 5 to $7 \mathrm{~g}$ fat. $100 \mathrm{~g}^{-1}$. About half of these fats are valuable monounsaturated fatty acids and only one third less healthy saturated fatty acids (Dowarah, 2013).
Meat proteins are characterized by good digestibility (about 94\%) (Williams, 2007) and a high amino acid score (AAS) $=0.92$ (Pereira and Vicente, 2013), while vegetable proteins of lentils, peas and chickpeas have an AAS value $=0.57$ -0.71 and wheat gluten only AAS $=0.25$. According to the Bobko et al. (2017) chicken meat contains an average of $22 \%$ protein. The average nutritional composition of the breast and thigh muscles is reported by Čuboň et al. (2013), resp. Haščík et al. (2014a): dry matter (\%) 25.8 resp. 26.0 for breasts and 33.1 resp. 32.6 for thighs; protein content $\left(\mathrm{g} .100 \mathrm{~g}^{-1}\right) 22.9$ resp. 23.0 for breasts and 19.5, resp. 19.2 for thighs; fat content $\left(\mathrm{g} .100 \mathrm{~g}^{-1}\right) 1.8$ for both authors for breasts and 12.7 resp. 12.6 for thighs. Cavani et al. (2009) adds for breasts, resp. thighs energy value (kcal) 104, resp. 115; cholesterol (mg) 62, resp. 80; Fe (mg) 0.72, resp. 1.02 and $\mathrm{Na}(\mathrm{mg}) 65$, resp. 86 .

The poultry industry has grown and improved in recent years thanks to the constant integration of individual sectors (poultry health, nutrition, breeding and processing). In modern breeding practices, a live weight of broilers of $1.8 \mathrm{~kg}$ can be achieved by using $3.2 \mathrm{~kg}$ of feed in 35 days without the addition of antibiotics (Diarra and Malouin, 2014). Pascalau et al. (2017) compared productive parameters of Ross 308 and Cobb 500 hybrids. Ross 308 hybrids reached live body weight $2219.19 \mathrm{~g}$, although Cobb 500 shoved a higher final body weight after 42 days (2297.75 g). However, Bjedov et al. (2011) found higher live body weight in Ross 308 compared to Cobb 500 (2592.00 vs. 2542.00 g). Overall broiler chickens are generally fattened until the age of 38 to 42 days, live weight is around $2.0 \mathrm{~kg}$, feed conversion $1.8 \mathrm{~kg}$, mortality up to $4 \%$ and carcass yield about $75 \%$ (Brouček et al., 2011).

In poultry farming, feed represents $70-75 \%$ of the total production costs Poultry feed is based primarily on cereals, especially corn, wheat, sorghum, soybeans and vegetable proteins, which meet the energy and protein requirements of poultry (Raza et al., 2019). Comfort, health and production efficiency are also important factors influencing broiler fattening. In the EU, broilers are usually kept on bedding in the well-ventilated halls without windows (Hui and Guerrero-Legarreta, 2010). In general, the quality of chicken meat depends on the nutrition of the chickens. Therefore, chicken nutrition is currently being enriched with additives such as probiotics, prebiotics, organic acids, enzymes, 
plant products and other antimicrobials to improve their health and performance (Pavelková et al., 2020). These additives are most often applied via water or feed (Trembecká et al., 2017). On the other hand, feed supplements should replace forbidden feed antibiotics and at the same time improve growth, nutritional parameters without adversely affecting meat. The intestinal microflora plays an important role in stimulating animal's growth, so these feed supplements should focus mainly on the intestinal tract. However, none of these supplements have been able to completely replace feed antibiotics, so there is still space for further research (Peng et al., 2014)

The vine is the most economically important crop in the world. Its fruits (grapes) are used for consumption, wine production as well as dried grapes and juices. In addition, the consumption of table grapes and wine has a number of nutritional and health benefits for humans due to biologically active substances, e.g resveratrol (Fortes and Pais, 2016). Wine production generates approximately five to nine million tons of waste per year (Lafka et al., 2007). As the stems are removed separately, the by-product contains only skins and seeds collectively referred as grape pomace. Grape pomace contains various phytochemicals rich in flavonoids, such as catechin, anthocyanin and epicatechin (Djilas et al., 2009; Turner, 2009). Grape seeds contain $8-15 \%$ of oils with high levels of unsaturated fatty acids, especially oleic and linoleic acids (Choi et al., 2010), which represent more than $89 \%$ of total fatty acids (Davidov-Pardo and McClements, 2015).

The large and available amounts and the amount of bioactive compounds present in grape pomace make them a suitable candidate for use in an animal nutrition (Aditya et al., 2018). The beneficial effects of grape pomace enrichment in poultry nutrition have been demonstrated in previous experiments (Kara et al. 2016; Kasapidou et al., 2016). For example, enrichment with grape pomace as a source of antioxidants at $30 \mathrm{~g} \cdot \mathrm{kg}^{-1}$ (Brenes et al., 2007) and $60 \mathrm{~g} . \mathrm{kg}^{-1}$ (Goni et al., 2006) reduced lipid oxidation in broiler chicken meat. Viveros et al. (2010) state, that the addition of grape pomace has increased the amount of beneficial bacteria in the broilers intestines.

The aim of the present study was to evaluate the meat performance following the addition of grape pomace in three different percentages into diet for Ross 308 broiler chicken.

\section{MATERIAL AND METHODS}

\section{Animals and experimental design}

The experiment was realized in the Slovak University of Agriculture (SUA) in Nitra (Test poultry station, Kolínany). The fattening period lasted for 42 days and the animals were kept under the same conditions. The experiment included 200 one-day-old chicks (Ross 308) of mixed sex randomly divided into 4 groups (each containing 50 chickens). The size of pen for one group of chickens was 3.2 x $2.4 \mathrm{~m}$. The broiler chickens were reared on breed litter (wood shavings), in a temperature-controlled room; ambient temperature in test poultry station was maintained at $33{ }^{\circ} \mathrm{C}$ during the first week and gradually decreased by $2{ }^{\circ} \mathrm{C}$, and finally fixed at $23{ }^{\circ} \mathrm{C}$ thereafter. The temperature and relative humidity were controlled. Over the entire fattening period, the chickens were provided with $a d$ libitum access to feed (shredded form) as well as drinking water and were kept under a constant light regime.

Diets were prepared to accommodate the nutrient requirements of broilers following the recommended reference levels (Bulletin of MARD SR, 2005), and broilers were subjected to a two phase feeding programme, starter HYD-01 (1 $21 \mathrm{~d})$ and grower HYD-02 (22 - 42 d) diets. The composition of basal diets is presented in Table 1. The starter and grower feed mixtures were produced without any antibiotics and coccidiostatics and were prepared by Biofeed, Inc. (Kolárovo, Slovak Republic). The experimental groups were set up as follows: the control group (C) involved the basal diet without supplementation; the experimental group of chickens (E1) was fed with basal diet plus red grape pomace $1 \% .100 \mathrm{~kg}^{-1}$ of feed mixture; experimental group E2 was fed with a complete feed mixture plus red grape pomace $2 \% .100 \mathrm{~kg}^{-1}$ of feed mixture and experimental group E3 was fed with a complete feed mixture plus red grape pomace $3 \% .100 \mathrm{~kg}^{-1}$ of feed mixture.

Table 1 Composition of feed mixtures

\begin{tabular}{lcc}
\hline Ingredients (\%) & $\begin{array}{c}\text { Starter (HYD-01) } \\
\left(\mathbf{1}^{\text {st }}-\mathbf{2 1}^{\text {st }} \text { day of age }\right)\end{array}$ & $\begin{array}{c}\text { Grower (HYD-02) } \\
\left(\mathbf{2 2}^{\text {nd }}-\mathbf{4 2}^{\text {th }} \text { day of age }\right)\end{array}$ \\
\hline Wheat & 34.50 & 30.00 \\
Maize & 28.00 & 39.00 \\
Soybean meal (48\% N) & 31.00 & 26.00 \\
Fodder lime & 0.65 & 0.60 \\
Calcium formate & 0.80 & 0.80 \\
Monocalcium & 0.90 & 0.55 \\
phosphate & 0.20 & 0.20 \\
Fodder salt & 0.20 & 0.20 \\
Sodium bicarbonate & 0.10 & 0.05 \\
Lysine & 0.15 & 0.15 \\
Methionine & 3.00 & 1.95 \\
Soybean oil & 0.50 & 0.50 \\
Premix Euromix BR & &
\end{tabular}

$0.5 \%^{*}$

Nutrient content $\left(\mathrm{g} \cdot \mathrm{kg}^{-1}\right)$

\begin{tabular}{lcc} 
Linoleic acid & 27.82 & 24.04 \\
Fibre & 28.71 & 27.84 \\
Crude protein & 209.68 & 189.60 \\
Ash & 45.45 & 39.59 \\
$\mathbf{C a}$ & 8.12 & 7.27 \\
$\mathbf{P}$ & 6.04 & 5.13 \\
$\mathbf{N a}$ & 1.61 & 1.58 \\
$\mathbf{M E}_{\mathbf{N}}\left(\mathbf{M J . k g}^{-1}\right)$ & 11.92 & 11.92 \\
\hline
\end{tabular}

*active substances per kilogram of premix: vitamin A 2,500,000 IU; vitamin $\mathrm{E}$ 50,000 mg; vitamin D3 800,000 IU; niacin 12,000 mg; D-pantothenic acid 3,000 mg; riboflavin 1,800 mg; pyridoxine $1,200 \mathrm{mg}$; thiamine $600 \mathrm{mg}$; methadione $800 \mathrm{mg}$; ascorbic acid $50,000 \mathrm{mg}$; folic acid $400 \mathrm{mg}$; biotin $40 \mathrm{mg}$; cobalamin $10.0 \mathrm{mg}$; choline 100,000 mg; betaine 50,000 mg; Mn 20,000 mg; Zn 16,000 mg; Fe 14,000 mg; Cu 2,400 mg; Co 80 mg; I 200 mg; Se 50 mg.

\section{Characterization of grape pomace applied in experiment}

Nutrient composition of red grape pomace (variety Alibernet - Table 2) was determined on the Department of Animal Nutrition (SUA, Nitra).

\begin{tabular}{|c|c|c|c|c|c|c|c|c|c|c|c|c|c|}
\hline \multirow{2}{*}{$\begin{array}{l}\text { Red } \\
\text { grape } \\
\text { pomace }\end{array}$} & DM & CP & $\mathbf{E E}$ & CF & Ah & NFE & OM & SG & ADF & NDF & $\mathbf{L}$ & $\mathrm{C}$ & H \\
\hline & 383.50 & 112.80 & 105.91 & 230.31 & 65.55 & 485.74 & 949.56 & 4.89 & 450.81 & 525.46 & 281.29 & 156.48 & 91.82 \\
\hline
\end{tabular}

Notes: $\mathrm{DM}=$ dry matter; $\mathrm{CP}=$ crude protein; $\mathrm{EE}=$ crude fat $\mathrm{CF}=$ crude fibre; $\mathrm{Ah}=$ ash $; \mathrm{NFE}=$ nitrogen free extracts; $\mathrm{OM}=$ organic matter; $\mathrm{SG}=$ sugar; $\mathrm{ADF}=$ acid detergent fibre; $\mathrm{NDF}=$ neutral detergent fibre; $\mathrm{L}=$ lignin; $\mathrm{C}-$ cellulose; $\mathrm{H}-$ hemicelluloses.

\section{Slaughter and measurements}

At 42 days of age, 20 chickens of mixed sex (10 10 and 10 ) were selected from each group based on the average weight, then weighed and slaughtered at the experimental slaughterhouse of the Department of Technology and Quality of Animal Products (SUA, Nitra). The chickens were slaughtered by conventional neck cut, bled, feathers removed, and eviscerated.

Examined parameters in experiment were as follows: live body weight (BW) $(\mathrm{g})$ at the and fattening period (42 d); carcass weight $(\mathrm{CW})(\mathrm{g})$; giblets weight $(\mathrm{g})$ liver weight $(\mathrm{g})$; gizzard weight $(\mathrm{g})$; heart weight $(\mathrm{g})$; neck weight $(\mathrm{g})$; breast part weight $(\mathrm{g})$; thigh part weight $(\mathrm{g})$; carcass yield $(\%)$.

\section{Statistical analysis}

Statistical analysis was calculated using ANOVA and SAS software with the Enterprise Guide 4.2 application (version 9.3, SAS Institute Inc., USA, 2008).
Results were reported as mean \pm standard deviation. Statistical significance was calculated using the t-test. Differences between the groups were considered significant at $\mathrm{P} \leq 0.05$.

\section{RESULTS AND DISCUSSION}

The ever-increasing consumption of animal products will also be related with increasing demand for feed. At present, more than a billion tonnes of food are thrown away every year. The use of agricultural waste as animal feed that can help to eliminate the feed shortage present in most developing countries. In addition, their use as feed puts them back in the food chain, thus alleviating the environmental problems that arise as a result of their decomposition. Their natural origin also fulfils the demands of consumers for "clean," "natural" and "eco/green" label food products. (Kasapidou, Sossidou and Mitlianga, 2015; Wadhwa, Bakshi and Makkar, 2015). Grape pomace belongs to such a waste and due to its nutritional composition has a high potential as an animal feed. The 
effect of grape pomace supplementation on meat performance of Ross 308 broiler chickens is shown in Table 3.

Table 3 Effect of grape pomace on meat performance parameters of broiler chickens Ross 308

\begin{tabular}{|c|c|c|c|c|c|c|}
\hline Parameter & Sex & C & E1 & E2 & E3 & P-value \\
\hline \multirow{3}{*}{ Live body weight (g) } & Male & $2118.60 \pm 67.74^{b}$ & $2196.60 \pm 53.43^{\mathrm{ab}}$ & $2128.60 \pm 45.31^{b}$ & $2225.40 \pm 47.86^{\mathrm{a}}$ & 0.0423 \\
\hline & Female & $1883.80 \pm 59.79^{\mathrm{b}}$ & $2053.60 \pm 123.79^{\mathrm{ac}}$ & $1980.40 \pm 84.46^{\mathrm{bc}}$ & $2136.40 \pm 57.31^{\mathrm{a}}$ & 0.0335 \\
\hline & $\hat{3}+0$ & $2001.20 \pm 137.63^{b}$ & $2125.10 \pm 137.63^{\mathrm{bc}}$ & $2054.50 \pm 100.92^{b}$ & $2180.90 \pm 68.40^{\mathrm{ac}}$ & 0.0125 \\
\hline \multirow[t]{3}{*}{ Carcass weight (g) } & Male & $1528.20 \pm 68.28$ & $1504.20 \pm 85.17$ & $1510.00 \pm 67.45$ & $1556.60 \pm 40.89$ & 0.3235 \\
\hline & Female & $1377.00 \pm 56.60^{\mathrm{b}}$ & $1380.60 \pm 102.15^{\mathrm{ab}}$ & $1418.80 \pm 92.53^{\mathrm{ab}}$ & $1475.00 \pm 39.40^{\mathrm{a}}$ & 0.0472 \\
\hline & $\hat{\jmath}+q$ & $1452.60 \pm 99.23$ & $1442.40 \pm 110.02$ & $1464.40 \pm 90.21$ & $1515.80 \pm 57.29$ & 0.1376 \\
\hline \multirow[t]{3}{*}{ Giblets weight (g) } & Male & $152.96 \pm 4.72$ & $166.60 \pm 9.18$ & $164.62 \pm 8.37$ & $157.72 \pm 8.82$ & 0.0663 \\
\hline & Female & $133.20 \pm 7.09^{\mathrm{b}}$ & $149.80 \pm 14.17^{\mathrm{bc}}$ & $152.60 \pm 8.86^{\mathrm{c}}$ & $154.22 \pm 6.26^{\mathrm{ac}}$ & 0.0472 \\
\hline & $\hat{j}+0$ & $143.08 \pm 11.86^{\mathrm{b}}$ & $158.20 \pm 14.32^{\mathrm{a}}$ & $158.61 \pm 10.31^{\mathrm{a}}$ & $155.97 \pm 7.44^{\mathrm{a}}$ & 0.0173 \\
\hline \multirow[t]{3}{*}{ Carcass yield (\%) } & Male & $79.35 \pm 1.53$ & $76.04 \pm 2.46$ & $78.65 \pm 2.00$ & $77.03 \pm 0.69$ & 0.0663 \\
\hline & Female & $80.16 \pm 0.90^{\mathrm{a}}$ & $74.48 \pm 1.51^{\mathrm{b}}$ & $79.31 \pm 1.99^{\mathrm{ac}}$ & $76.29 \pm 1.97^{\mathrm{bc}}$ & 0.0335 \\
\hline & $\hat{\jmath}+q$ & $79.75 \pm 1.26^{\mathrm{a}}$ & $75.26 \pm 2.09^{\mathrm{b}}$ & $78.98 \pm 1.91^{\mathrm{a}}$ & $76.66 \pm 1.45^{\mathrm{b}}$ & 0.0023 \\
\hline \multirow[t]{3}{*}{ Liver (g) } & Male & $36.02 \pm 2.99$ & $33.44 \pm 2.59$ & $33.12 \pm 3.14$ & $34.72 \pm 2.96$ & 0.1290 \\
\hline & Female & $32.34 \pm 1.74$ & $33.58 \pm 3.19$ & $31.54 \pm 3.52$ & $32.74 \pm 3.75$ & 0.5464 \\
\hline & $\hat{\jmath}+q$ & $34.18 \pm 3.01$ & $33.51 \pm 2.74$ & $32.33 \pm 3.25$ & $33.73 \pm 3.35$ & 0.1565 \\
\hline \multirow[t]{3}{*}{ Gizzard $(\mathrm{g})$} & Male & $34.00 \pm 5.61$ & $38.44 \pm 6.53$ & $36.46 \pm 4.52$ & $36.54 \pm 5.11$ & 0.2403 \\
\hline & Female & $33.66 \pm 4.01$ & $32.78 \pm 4.89$ & $34.16 \pm 2.35$ & $33.68 \pm 1.28$ & 0.7598 \\
\hline & $j+q$ & $33.83 \pm 4.60$ & $35.61 \pm 6.20$ & $35.31 \pm 3.61$ & $35.11 \pm 3.82$ & 0.5280 \\
\hline \multirow[t]{3}{*}{ Heart $(\mathrm{g})$} & Male & $10.50 \pm 1.07$ & $11.34 \pm 0.96$ & $10.72 \pm 0.36$ & $10.74 \pm 2.39$ & 0.2403 \\
\hline & Female & $10.32 \pm 1.87$ & $10.76 \pm 0.97$ & $9.80 \pm 0.59$ & $9.04 \pm 0.55$ & 0.1249 \\
\hline & $\hat{3}+0$ & $10.41 \pm 1.44^{\mathrm{ab}}$ & $11.05 \pm 0.96^{\mathrm{a}}$ & $10.26 \pm 0.67^{\mathrm{ab}}$ & $9.89 \pm 1.87^{\mathrm{b}}$ & 0.0276 \\
\hline \multirow[t]{3}{*}{ Neck (g) } & Male & $72.44 \pm 7.30^{\mathrm{b}}$ & $83.38 \pm 4.31^{\mathrm{a}}$ & $84.32 \pm 7.75^{\text {ab }}$ & $75.72 \pm 4.68^{\text {ab }}$ & 0.0472 \\
\hline & Female & $56.88 \pm 4.97^{\mathrm{b}}$ & $72.68 \pm 8.60^{\mathrm{a}}$ & $77.10 \pm 5.34^{\mathrm{a}}$ & $78.76 \pm 4.00^{\mathrm{a}}$ & 0.0335 \\
\hline & $\hat{\jmath}+q$ & $64.66 \pm 10.09^{\mathrm{b}}$ & $78.03 \pm 8.54^{\mathrm{a}}$ & $80.71 \pm 7.33^{\mathrm{a}}$ & $77.24 \pm 4.41^{\mathrm{a}}$ & 0.0064 \\
\hline \multirow[t]{3}{*}{ Breast (g) } & Male & $471.31 \pm 68.27^{b}$ & $514.23 \pm 74.12^{\mathrm{ab}}$ & $523.46 \pm 31.76^{\mathrm{ab}}$ & $557.63 \pm 41.19^{\mathrm{a}}$ & 0.0490 \\
\hline & Female & $425.09 \pm 40.41^{\mathrm{b}}$ & $469.46 \pm 48.46^{\mathrm{ab}}$ & $510.97 \pm 27.00^{\mathrm{a}}$ & $534.89 \pm 31.08^{\mathrm{a}}$ & 0.0335 \\
\hline & $\hat{3}+0$ & $448.20 \pm 58.23^{\mathrm{b}}$ & $491.84 \pm 63.58^{\mathrm{ab}}$ & $517.21 \pm 28.56^{\mathrm{a}}$ & $546.26 \pm 36.43^{\mathrm{a}}$ & 0.0076 \\
\hline \multirow[t]{3}{*}{ Thigh (g) } & Male & $469.02 \pm 22.06^{\mathrm{ab}}$ & $465.39 \pm 27.92^{\mathrm{ab}}$ & $446.83 \pm 19.37^{b}$ & $489.38 \pm 20.52^{\mathrm{a}}$ & 0.0472 \\
\hline & Female & $410.97 \pm 33.06$ & $430.05 \pm 39.81$ & $427.86 \pm 28.17$ & $439.11 \pm 12.78$ & 0.3235 \\
\hline & $3+0$ & $440.00 \pm 40.47$ & $447.72 \pm 37.38$ & $437.34 \pm 24.89$ & $464.25 \pm 31.01$ & 0.0796 \\
\hline
\end{tabular}

Notes: Values shown as mean $\pm S D$ (standard deviation); $\mathrm{C}=$ control group; E1, E2, E3 = experimental groups; $\mathrm{a}, \mathrm{b}, \mathrm{c}=$ means within a row with different superscripts differ significantly at $\mathrm{P} \leq 0.05$, one-way ANOVA.

Based on the achieved results, we can state that the live weight of chickens was significantly highest $(\mathrm{P}<0.05)$ in the group E3 $(\hat{\sigma}-2225.40 \mathrm{~g}$, + $-2136.40 \mathrm{~g}$ and $\hat{\delta}+q-2180.90 \mathrm{~g})$ in comparison with control group $(\hat{\delta}-2118.60 \mathrm{~g}$, + $1883.80 \mathrm{~g}, \hat{\delta}+\mathrm{P}-2001.20 \mathrm{~g}$ ). Our live body weight results are comparable with results of Tekeli, Rustu Kutlu and Celik (2014) who observed slightly higher body weight in the group fed with the diet containing $15 \mathrm{~g}_{\mathrm{kg}} \mathrm{kg}^{-1}$ grapeseed oil (2251.96 g), compared to control group (2199.36 g). Sossidou et al. (2013) observed lower supplementations with dried grape pomace into Ross 308 broiler chicken diet $(0.25,0.5$ and $1 \%)$. In comparison with control group, the highes live body weight was observed after $1 \%$ addition $-2535.13 \mathrm{~g}(\mathrm{P}<0.05)$, while lower additions of grape pomace did not affect this parameter, which is also in line with the results of our experiment at the highest concentration of red grape pomace $(3 \%)$ in complete feed mixture for Ross 308 chickens. Turcu et al. (2020) found a lower live body weight of Cobb 500 chickens after application of red grape pomace (variety Merlot) (P> 0.05) in an amount of 3 and 6\% (2937.73 $\mathrm{g}$ and $2995.74 \mathrm{~g}$ ) compared to the control group (3136.67 g), which is in contrast to results achieved by us. Research of Kumanda, Mlambo and Mnisi (2019a) shows significant decrease $(\mathrm{P}<0.05)$ of body weight $(2844.90 \mathrm{~g})$ after high dosage of $10 \%$ untreated red grape pomace compared to control group (2957.50 g). High dosage with white grape pomace flour $(20 \%)$ also did not lead to an improvement of body weight in study of Reyes et al. (2020). However, higher final body weight was observed by Turcu et al. (2019) in Hubbard broilers supplemented with $2 \%$ grapeseed meal in comparison with control group ( 2719.47 vs. 2545.00 g). Other supplementations may also adverse body weight of broiler chicken (Haščík et al., 2018). For example, Haščík et al. (2019) observed significant $(\mathrm{P}<0.05)$ increase after addition of $400 \mathrm{mg}$ bee pollen extract per $1 \mathrm{~kg}$ of feed mixture plus $3.3 \mathrm{~g}$ probiotic (Lactobacillus fermentum) added to drinking water on a daily basis $(2401.70 \mathrm{~g})$ and also increase of body weight $(\mathrm{P}>0.05)$ using the same supplementation with propolis instead of bee pollen $(2358.00 \mathrm{~g})$ compared to control group (2270.2 g).

When evaluating the carcass weight, we found significant differences $(\mathrm{P}<0.05)$ only in females between group C (1377.00 g) and E3 (1475.00 g). Our results are comparable with Tekeli, Rustu Kutlu and Celik (2014), who found the highest carcass weight after the highest used grapeseed oil supplementation (1.5\%) $1540.31 \mathrm{~g}$, what was $10.16 \mathrm{~g}$ more than in control group (1530.15 g). Markedly lower carcass weight was described by Kumanda, Mlambo and Mnisi (2019b) who did not find positive effects of red grape pomace supplementation, cold carcass weight decreased in $2.5,4.5,5.5$ and $7.5 \%$ as followed: $1229.2,1237.1$, 1161.9 and $1153.1 \mathrm{~g}$, respectively, in comparison with control group $(1270.7 \mathrm{~g})$. Much higher carcass weight $\mathrm{P}<0.05$ ) was observed by Sossidou et al. (2013) after addition of dried grape pomace in amount of $0,5 \%(1953.08 \mathrm{~g})$ and $1 \%$ $(1950.00 \mathrm{~g})$ compared to control group $(1884.44 \mathrm{~g})$. Sánchez-Roque et al.
(2017) observed the effect of different agro industrial wastes on carcass characteristics of broiler chickens. They found significantly higher carcass weight $(\mathrm{P}<0.05)$ after supplementation with ferment of coffee $(1810.10 \mathrm{~g})$ and milk whey $(1718.2 \mathrm{~g})$ in comparison with control group (1463.00 g).

Significantly higher weight of giblets in the experimental groups $(\mathrm{P}<0.05)$ compared to the control group were found in females in the E2 and E3 groups and without gender difference in the E1, E2 and E3 groups. The weight of the liver, gizzard and heart was not significantly affected $(\mathrm{P}<0.05)$ by the addition of red grape pomace compared to the control, but the weight of the necks was significantly affected $(\mathrm{P}<0.05)$ in all experimental groups E1, E2 and E3 ( $($ and $\widehat{0}+$ +). Similar total giblets weight was observed by Haščík et al. $(\mathbf{2 0 1 5}, \mathbf{2 0 1 9})$ using bee products and probiotics (ranging from 152.08 to $162.18 \mathrm{~g}$ ), while Hašč́k et al. $(2010,2013)$ found much lower giblets weight using propolis and propolis extract in the broiler chicken nutrition (117.16 - 140.75 g). According to Aditya et al. (2018), supplementation of grape pomace in broiler chicken diet did not show any effect on carcass traits such as abdominal fat, heart, liver, spleen, and thymus. Liver weight was slightly decreased by use of grapeseed oil in research of Tekeli, Rustu Kutlu and Celik (2014), however it was much higher $(\sim 42.00 \mathrm{~g})$ compared with our research. Our results of liver and gizzard weight are similar to Kumanda, Mlambo and Mnisi (2019b), who also did not find any significant differences between experimental groups of chickens fed by grape pomace. Comparable results were discovered by Sánchez-Roque et al. (2017) using different agricultural wastes (molasses, ferment of coffee and milk whey), when liver weight was ranging from 33.00 to $35.60 \mathrm{~g}$.

The significantly highest carcass yield $(\mathrm{P}<0.05)$ was recorded in the control group in females $(80.16 \%)$ compared to group E1 $(74.48 \%)$, resp. in chickens without gender difference between the control group $(79.75 \%)$ and the E1 group $(75.26 \%)$, resp. E3 $(76.66 \%)$. However, the carcass yield values in the experimental groups did not decrease significantly and remained several percent above the level of the minimum standardized yield of $72 \%$ (Haščík et al., 2014b). Our results shows much higher carcass yield compared to Tekeli, Rustu Kutlu and Celik (2014), who also did not found significant differences among the groups after grapeseed oil supplementation into chicken diet. While carcass yield decreased in the groups fed with 0.5 and $1 \%$ grape seed oil supplementation (68.81 and $68.07 \%)$, carcass yield of the group fed with $1.5 \%$ grape seed oil supplementation was similar $(69.80 \%)$ to that of the control group $(69.83 \%)$. Also according to Aditya et al. (2018), Haščík et al. (2019) and Kumanda, Mlambo and Mnisi (2019a) supplementation with grape pomace, probiotics and bee products in broiler chickens diet did not show any positive effect on carcass yield. Positive effect of grape pomace on carcass yield was observed by Kumanda, Mlambo and Mnisi (2019b) after $4.5 \%$ supplementation $(72.43 \%)$ compared to control group $(69.64 \%)$. Our results are also comparable with 
propolis supplementation by Haščík et al. (2010), who found that the carcass yield of Ross 308 chickens without gender difference was slightly higher in the control group (78.69\%) compared to the experimental group $(78.48 \%)$ but without significant differences $(\mathrm{P}>0.05)$. By sex, the carcass yield $(\mathrm{P}>0.05)$ was slightly higher in the control group $(78.78 \%)$ ) compared to the experimental group $(78.26 \%)$

Valuable meat parts (breasts, thighs) are the most important parts of the carcass of chickens and in our experiment we found $(\mathrm{P}<0.05)$ higher weight of breasts in males between control (471.31 g) and group E3 $(557.63 \mathrm{~g})$, in females between control group (425.09 g) and group E2 (510.97 g), respectively. E3 (534.89 g) and without gender difference between control (448.20 g) and group E2 (517.21 g) and group E3 (546.26 g). By evaluating the weight of the thigh part in Ross 308 chickens, we did not find significant differences $(\mathrm{P}<0.05)$ between the control and experimental groups according to or without a difference in sex. Supplementation with grape seed extract $(0.015-0.045 \%)$ increased the percentage of both breast $(23.05-24.93 \%)$ and thigh $(17.79-17.92 \%)$ compared to control group (breast $-22.83 \%$, thigh $-17.35 \%$ ) in study of Hajati et al (2015). On the other side, Ebrahimzadeh et al. (2018) found much higher breas percentage (\% of live weight) after $10 \%$ grape pomace supplementation $(29.31 \%)$ compared to control $(27.17 \%)$, the best thigh percentage in this study was described after addition of $5 \%$ grape pomace (19.15\%) compared to control group (18.79\%). Study of Haščík et al. (2019) evaluated, that supplementation with bee products and probiotics caused a slightly decrease of valuable parts weight, but the weight of the breast part was higher in their results $(621.34$ $667.48 \mathrm{~g})$ than in our experiment $(448.20-546.26 \mathrm{~g})$ and the weight of the thigh part was balanced.

\section{CONCLUSION}

This study was designed to determine the effect of dietary supplementation with red grape pomace (variety Alibernet) on the meat performance and carcass characteristics of broiler chickens Ross 308. Among the most noteworthy parameters affected positively $(\mathrm{P} \leq 0.05)$ by this supplement in comparison with control may be mentioned the live weight and breast part weight (male, female and $\hat{\sigma}++$ ), while grape pomace negatively affected mainly the carcass yield (female and $\hat{\jmath}+q$ ) as confirmed by other authors.

To conclude, addition of red grape pomace to broiler chicken feed mixture may be a fine way to utilize this voluminous agricultural waste. However, further research in term of other supplementation percentages as well as testing grape pomace from white grape varieties, is required to confirm these results.

Acknowledgments: This work was financially supported by the KEGA project 027SPU-4/2019, VEGA project 1/0722/19 and VEGA project 1/0147/19.

\section{REFERENCES}

Aditya, S., Ohh, S.-J., Ahammed, M., \& Lohakare, J. (2018). Supplementation of grape pomace (Vitis vinifera) in broiler diets and its effect on growth performance, apparent total tract digestibility of nutrients, blood profile, and meat quality. Animal Nutrition, $210-214$ https://doi.org/10.1016/j.aninu.2018.01.004

Bjedov, S., Ljubojevic, D. B., Milosevic, N., Stanacev, V., Djukic-Stojcic, M., \& Milic, D. (2011). Production performance of meat type hybrids. Biotechnology in Animal Husbandry, 27(4), 1689-1696. https://doi.org/10.2298/bah1104689b Bobko, M., Haščík, P., Bobková, A., Kročko, M., Tóth, T. (2017). Vplyv rôznych krmnych doplnkov na obsah tuku a oxidačnú stabilitu kuracieho mäsa. Český Těšín: 2 THETA. 112 p.

Brenes, A., Viveros, A., Goñi, I., Centeno, C., Sáyago-Ayerdy, S. G., Arija, I., \& Saura-Calixto, F. (2008). Effect of Grape Pomace Concentrate and Vitamin E on Digestibility of Polyphenols and Antioxidant Activity in Chickens. Poultry Science, 87(2), 307-316. https://doi.org/10.3382/ps.2007-00297

Brouček, J., Benková, J., Šoch, M. (2011). Technologie a technika chovu drůbeže při splněni podminek welfare. České Budějovice: Jihočeská univerzita.

Bulletin of MARD SR (Ministry of Agriculture and Rural Development of the Slovak Republic). 2005. Decree of Ministry of Agriculture and Rura Development of the Slovak Republic no. 2080/2005-100 of 23 March 2005 changing and amending Decree of Ministry of Agriculture and Rural Development of the Slovak Republic no. 1497/1/1997-100 of 7 October 1997 regulating feed materials for the manufacture of feed mixtures and farm feeds.

Cavani, C., Petracci, M., Trocino, A., \& Xiccato, G. (2009). Advances in research on poultry and rabbit meat quality. Italian Journal of Animal Science, 8(2), 741-750. https://doi.org/10.4081/ijas.2009.s2.741

Choi, Y.-S., Choi, J.-H., Han, D.-J., Kim, H.-Y., Lee, M.-A., Kim, H.-W., Lee, J.-W., Chung, H.-J. \& Kim, C.-J. (2010). Optimization of replacing pork back fat with grape seed oil and rice bran fiber for reduced-fat meat emulsion systems Meat Science, 84(1), 212-218. https://doi.org/10.1016/j.meatsci.2009.08.048 Čuboň, J., Haščík, P., Eliman, I. O. E., Garlík, J., Kačániová, M., \& Mohammed, H. A. (2013). The influence of bee pollen on the meat chemical composition for broiler's Ross 308 muscles. Journal of Microbiology, Biotechnology and Food Sciences, 2(1), 1128-1137
Davidov-Pardo, G., \& McClements, D. J. (2015). Nutraceutical delivery systems: Resveratrol encapsulation in grape seed oil nanoemulsions formed by spontaneous emulsification. Food Chemistry, 167, 205-212 https://doi.org/10.1016/j.foodchem.2014.06.082

Diarra, M. S., \& Malouin, F. (2014). Antibiotics in Canadian poultry productions and anticipated alternatives. Frontiers in Microbiology, 5.282 https://doi.org/10.3389/fmicb.2014.00282

Djilas, S., Canadanovic-Brunet, J., \& Cetkovic, G. (2009). By-products of fruits processing as a source of phytochemicals. Chemical Industry and Chemical Engineering Quarterly, 15(4), 191-202. https://doi.org/10.2298/ciceq0904191d

Dowarah, R. (2013). The role of poultry meat and eggs in human nutrition. Poultry line, 2013: 31-33

Ebrahimzadeh, S. K., Navidshad, B., Farhoomand, P., \& Mirzaei Aghjehgheshlagh, F. (2018). Effects of grape pomace and vitamin E on performance, antioxidant status, immune response, gut morphology and histopathological responses in broiler chickens. South African Journal of Animal Science, 48(2), 324. https://doi.org/10.4314/sajas.v48i2.13

FAO. (2019). Food Outlook - Biannual Report on Global Food Markets. Rome, Italy: http://www.fao.org/3/ca4526en/ca4526en.pdf

Fortes, A. M. \& Pais, M. S. 2016. Chapter 12 - Grape (Vitis species). Nutritional Composition of Fruit Cultivars. Academic Press: 257-286. https://doi.org/10.1016/B978-0-12-408117-8.00012-X

Goñi, I., Brenes, A., Centeno, C., Viveros, A., Saura-Calixto, F., Rebolé, A., Arija, A., \& Estevez, R. (2007). Effect of Dietary Grape Pomace and Vitamin E on Growth Performance, Nutrient Digestibility, and Susceptibility to Meat Lipid Oxidation in Chickens. Poultry Science, 86(3), 508-516. https://doi.org/10.1093/ps/86.3.508

Hajati, H., Hassanabadi, A., Golian, A.G., Nassiri-Moghaddam, H., \& Nassiri, M.R. (2015). The Effect of Grape Seed Extract and Vitamin C Feed Supplements Carcass Characteristics, Gut Morphology and Ileal Microflora in Broiler Chickens Exposed to Chronic Heat Stress. Iranian Journal of Applied Animal Science, 5(1), 155-165.

Haščík, P., Elimam, I. O. E., Garlík, J., Bobko, M., Kačániová, M., \& Čuboň, J. (2014a). Broiler's Ross 308 meat chemical composition after addition of bee pollen as a supplement in their feed mixtures. Journal of Microbiology, Biotechnology and Food Sciences, 3(3), 11-13.

Haščík, P., Kačániová, M., \& Vavrišinová, K. (2014b). Vplyv probiotických preparátov na jatočné ukazovatele a senzorickú kvalitu mäsa výkrmových kurčiat. Nitra: SUA, $162 \mathrm{p}$.

Haščík, P., Garlík, J., Elimam, I. O. E., Kňazovická, V., Kačániová, M., Šimko, M., \& Mellen, M. (2013). Meat performance of chickens Hubbard JV after application of propolis extract. Journal of Microbiology, Biotechnology and Food Sciences, 3(2), 118-121.

Haščík, P., Melich, M., Kačániová, M., Pál, G., Mihok, M., Čuboň, J., Mellen, M., \& Vavrišinová, K. (2010). The influence of propolis application to meat utility on ross 308 broiler chickens. Potravinarstvo Slovak Journal of Food Sciences, 4(2), 29-34

Haščík, P., Pavelková, A., Arpášová, H., Čuboň, J., Kačániová,, M., \& Simona Kunová. (2019). The effect of bee products and probiotic on meat performance of broiler chickens. Journal of Microbiology, Biotechnology and Food Sciences, 9(1), 88-92. https://doi.org/10.15414/jmbfs.2019.9.1.88-92

Haščík, P., Trembecká, L., Bobko, M., Čuboň, J., Tóth, T., \& Ducková, V. (2018). Effect of natural feed supplements on meat performance and meat quality of broiler chickens. Český Těšín: 2 THETA. $146 \mathrm{p}$

Haščík, P., Trembecká, L., Tkáčová, J., Kročko, M., Cuboň, J., \& Kačániová, M. (2015). Effect of bee pollen dietary supplementation on meat performance of ross 308 broiler chickens. Journal of Microbiology, Biotechnology and Food Sciences, 4(3), 55-58. https://doi.org/10.15414/jmbfs.2015.4.special3.55-58

Hui, Y. H., \& Guerrero-Legarreta, I. (2010). Poultry Biology, Classification, and Trade Descriptions. Handbook of Poultry Science and Technology, 1-18 Hoboken: John Wiley \& Sons. https://doi.org/10.1002/9780470504451.ch1 Kara, K., Kocaoğlu Güçlü, B., Baytok, E., \& Şentürk, M. (2015). Effects of grape pomace supplementation to laying hen diet on performance, egg quality, egg lipid peroxidation and some biochemical parameters. Journal of Applied Animal Research, 44(1), 303-310. https://doi.org/10.1080/09712119.2015.1031785

Kasapidou, E., Soddidou, E.N., Zdragas, A., Papadaki, C., Vafeas, G., \& Mtlianga P. (2016). Effect of grape pomace supplementation on broiler meat quality characteristics. European Poultry Science, 80, 135-142. https://doi.org/10.1399/eps.2016.135

Kasapidou, E., Sossidou, E., \& Mitlianga, P. (2015). Fruit and Vegetable CoProducts as Functional Feed Ingredients in Farm Animal Nutrition for Improved $\begin{array}{llll}\text { Product } & \text { Quality. } & \text { 5 } & \text { 1020-1034 }\end{array}$ https://doi.org/10.3390/agriculture5041020

Kumanda, C., Mlambo, V., \& Mnisi, C. (2019b). From Landfills to the Dinner Table: Red Grape Pomace Waste as a Nutraceutical for Broiler Chickens. Sustainability, 11(7), 1931. https://doi.org/10.3390/su11071931

Kumanda, C., Mlambo, V., \& Mnisi, C. M. (2019a). Valorization of Red Grape Pomace Waste Using Polyethylene Glycol and Fibrolytic Enzymes: Physiologica and Meat Quality Responses in Broilers. Animals, 9(10), 779 https://doi.org/10.3390/ani9100779 
Lafka, T.-I., Sinanoglou, V., \& Lazos, E. S. (2007). On the extraction and antioxidant activity of phenolic compounds from winery wastes. Food Chemistry, 104(3), 1206-1214. https://doi.org/10.1016/j.foodchem.2007.01.068

Pascalau S., Cadar M., Raducu C., \& Marchis Z. (2017). Evaluation of productive performances in Ross 308 and Cobb 500 hybrids. ABAH Bioflux, 9(1), 22-27.

Pavelková, A., Haščík, P., Kalafová, A., Capcarová, M., Čuboň, J., Bučko, O., Kačániová, M., Hanusová, E., Tkáčová, J., \& Bobko, M. (2020). Chemica composition of muscle after bee bread application in the nutrition of japanese quails. Journal Of Microbiology, Biotechnology and Food Sciences, 9 (4): 831835. https://doi.org/10.15414/jmbfs.2020.9.4.831-835

Peng, M., Salaheen, S., \& Biswas, D. (2014). Animal Health: Global Antibiotic Issues. Encyclopedia of Agriculture and Food Systems, 346-357. https://doi.org/10.1016/b978-0-444-52512-3.00187-x

Pereira, P. M. de C. C., \& Vicente, A. F. dos R. B. (2013). Meat nutritional composition and nutritive role in the human diet. Meat Science, 93(3), 586-592. https://doi.org/10.1016/j.meatsci.2012.09.018

Petracci, M., Bianchi, M., Mudalal, S., \& Cavani, C. (2013). Functional ingredients for poultry meat products. Trends in Food Science \& Technology, 33(1), 27-39. https://doi.org/10.1016/j.tifs.2013.06.004

Raza, A., Bashir, S., \& Tabassum, R. (2019). An update on carbohydrases: growth performance and intestinal health of poultry. Heliyon, 5(4), e01437. https://doi.org/10.1016/j.heliyon.2019.e01437

Reyes, P., Urquiaga, I., Echeverría, G., Durán, E., Morales, M. S., \& Valenzuela C. (2020). Wine grape pomace flour in broiler diets effects growth and some meat characteristics. Animal Production Science, 60(9), 1210. https://doi.org/10.1071/an19385

Sanchez-Roque, Y., Perez-Luna, Y. D. C., Perez-Luna, E., Berrones-Hernandez, R., \& Saldana-Trinidad, S. (2017). Evaluation of different agroindustrial waste on the effect of different carcass characteristics and physiological and biochemical parameters in broilers chicken. Veterinary World, 10(4), 368-374. https://doi.org/10.14202/vetworld.2017.368-374

Shaltout, F. (2019). Poultry meat. Scholarly Journal of Food and Nutrition Editorial, 2(2), 209-210. https://doi.org/10.32474/SJFN.2019.02.000134

Sossidou, E.N., Kasapidou, E., Dotas, V., Ioannidis, I. \& Mitlianga, P. (2013). Effect of grape pomace supplementation on broiler performance and eating quality. Book of Abstracts of the 64th Annual Meeting of the European Association for Animal, 405.

Tekeli, A., RuStu Kutlu, H. \& L. Celik. (2014). Dietary Inclusion of Grape Seed Oil in Functional Broiler Meat Production. Bulgarian Journal of Agricultural Science, 20(4), 924-932.

Trembecká, L., Haščík, P., Čuboň, J., Bobko, M., Cviková, P., \& Hleba, L. (2017). Chemical and sensory characteristics of chicken breast meat after dietary supplementation with probiotic given in combination with bee pollen and propolis. Journal of Microbiology, Biotechnology and Food Sciences, 7(3), 275280. https://doi.org/10.15414/jmbfs.2017/18.7.3.275-280

Turcu, R. P., Panaite, T. D., Untea, A. E., Șoica, C., Iuga, M., \& Mironeasa, S. (2020). Effects of Supplementing Grape Pomace to Broilers Fed Polyunsaturated Fatty Acids Enriched Diets on Meat Quality. Animals, 10(6), 947 https://doi.org/10.3390/ani10060947

Turcu, R., Olteanu, M., Criste, R., Panaite, T., Ropotă, M., Vlaicu, P., \& Drăgotoiu, D. (2019). Grapeseed Meal Used as Natural Antioxidant in High Fatty Acid Diets for Hubbard Broilers. Brazilian Journal of Poultry Science, 21(2). https://doi.org/10.1590/1806-9061-2018-0886

Turner, M.K. (2009). Anthocyanins increase antioxidant enzyme activity in ht-29 adenocarcinoma cells: Doctoral degree thesis Dissertation. The University of Georgia, USA.

Viveros, A., Chamorro, S., Pizarro, M., Arija, I., Centeno, C., \& Brenes, A. (2011). Effects of dietary polyphenol-rich grape products on intestinal microflora and gut morphology in broiler chicks. Poultry Science, 90(3), 566-578 https://doi.org/10.3382/ps.2010-00889

Wadhwa, M., Bakshi, M., \& Makkar, H. (2015). Waste to worth: fruit wastes and by-products as animal feed. CAB Reviews, 10(31), 1-26. https://doi.org/10.1079/PAVSNNR201510031

Williams, P. (2007). Nutritional composition of red meat. Nutrition \& Dietetics, 64(4), 113-119. https://doi.org/10.1111/j.1747-0080.2007.00197.x 